\title{
TOWARDS THE INSTITUTIONALIZATION OF COSMOPOLITAN LAW-MAKING
}

\author{
YOSHIAKI SATO*
}

The emergence of de facto cosmopolitan lawmaking activities, as well as the institutionalization of cosmopolitan law-making, is gradually changing the transnational legal landscape. This article explains the original concept of cosmopolitan law as it was first put forward by Immanuel Kant and describes how the emergence of de facto cosmopolitan law-making activities has resulted in the adoption of various treaties and international norms. It identifies the two types of institutionalization of cosmopolitan lawmaking as a hybrid of international and cosmopolitan law-making, and a purer version of cosmopolitan lawmaking. The article then argues that in order for cosmopolitan law-making to be recognized as legitimate, cosmopolitans must limit themselves to advisory roles and remain accountable to stakeholders around the world. The article concludes by discussing the proposed "Draft Charter of the East Asian Community" as an epoch-making proposal for regional integration in East Asia.
L'émergence d'activités législatives cosmopolites de facto, ainsi que l'institutionnalisation du droit cosmopolite est en train de progressivement changer le paysage juridique transnational. Cet article examine le concept original de droit cosmopolite tel qu'il avait été présenté par Emmanuel Kant et décrit de quelle manière l'émergence d'activités législatives cosmopolites de facto a amené l'adoption de plusieurs traités et normes internationales. Il identifie deux types d'institutionnalisation du droit cosmopolite comme étant une forme hybride du droit international et du droit cosmopolite et une version plus pure du droit cosmopolite. L'article fait ensuite valoir que pour que le droit cosmopolite soit reconnu comme étant légitime, les cosmopolitiques doivent se limiter à des rôles consultatifs et demeurer responsables envers les intervenants partout dans le monde. L'article se termine sur une discussion du Projet de Charte des communautés de l'Asie de l'Est («Draft Charter of the East Asian Community») proposé comme une proposition faisant date pour l'intégration de l'Asie de l'Est.

\section{TABLE OF CONTENTS}

I. INTRODUCTION .................................. 1142

II. TWO ASPECTS OF COSMOPOLITAN LAW

ADVOCATED BY IMMANUEL KANT . . . . . . . . . . . . . . . 1145

III. EMERGENCE OF DE FACTO COSMOPOLITAN LAW-MAKING . . . . . . . 1147

IV. INSTITUTIONALIZATION OF COSMOPOLITAN LAW-MAKING: THE EuRoPeAn Union AS the Most AdVANCEd Form . . . . . . . . 1151

V. CONDITIONS FOR COSMOPOLITAN LAW-MAKING: ADVISORY

CHARACTER AND ACCOUNTABILITY $\ldots \ldots \ldots \ldots \ldots \ldots \ldots \ldots . \ldots 1153$

VI. THE "DRAFT CHARTER OF THE EASt ASIAN COMMUNITY":

AN EXAMPLE OF A PROPOSAL FOR ESTABLISHING AN

INSTITUTION OF COSMOPOLITAN LAW-MAKING . . . . . . . . . . . . 1155

VII. CONCLUSION ................................... 1159

LL.B., LL.M., Ph.D., University of Tokyo; Associate Professor of Law, Seikei University, Japan. For their valuable comments, the author thanks Keisuke Mark Abe, Jaye Ellis, Jeremy Farrall, Joanna Harrington, Amichai Magen, Graham Mayeda, and Shigeki Sakamoto. 


\section{INTRODUCTION}

It is well accepted that international law is a form of law that governs the global community, and that it is composed of customary law, treaties, and general principles of law. ${ }^{1}$ Traditionally, all of these sources of law were understood to be the creations of states. However, it is now recognized that states themselves are disaggregating into their functionally distinct parts. $^{2}$ Thus, in order to understand the process of international lawmaking, it is necessary to focus on transgovernmental actions of each department of each relevant government as opposed to looking at each state as a "black box." Otherwise, it might be overlooked that a typical "agency problem"3 would occur if such a rule of transgovernmental law was established beyond the control of elected branches of government because the interests of a governmental body in charge of such law-making may not coincide with the interests of the state as a whole. ${ }^{4}$

Additionally, as more and more private actors become involved in activities conducted across national boundaries, it has become necessary to develop a concept to cover the other types of law-making that regulate such activities, whether they be national or international in scope. In 1956, Columbia University law professor Philip C. Jessup ${ }^{5}$ coined the term "transnational law" to serve as a comprehensive notion to assist with the understanding of this trend. ${ }^{6}$ Yale University law professor and former Assistant Secretary of State ${ }^{7}$ Harold Hongju Koh has further developed this overlooked concept in recent years. ${ }^{8}$ Professor Koh has identified four distinctive features of the transnational legal process: it transcends traditional dichotomies between domestic and international as well as public and private; it focuses on non-state actors in addition to nation-states; it is dynamic rather than static; and it aims at understanding why nations obey law. ${ }^{9}$

The concept of transnational law has had a heuristic meaning for scholars and practitioners alike in that it freed them from the classical dichotomy between national law and international law. Yet, those who promoted the concept seldom examined the process of lawmaking that was relevant to each set of rules of transnational law. As the title of one of his

See Statute of the International Court of Justice, 26 June 1945, Can. T.S. 1945 No. 7, art. 38(1). See also Sir Robert Jennings \& Sir Arthur Watts, eds., Oppenheim's International Law, 9th ed. (London: Longman, 1992) vol. 1 at 24-25.

See Anne-Marie Slaughter, “The Real New World Order” (1997) 76 Foreign Affairs 183 at 183-184. An agency problem occurs where, because of asymmetrical information or randomness, an agent can choose whether to serve or exploit the principal: see Robert Cooter \& Thomas Ulen, Law and Economics, 5th ed. (Boston: Pearson Education, 2008) at 431-34.

For example, bureaucrats in the defence ministries of the North American Treaty Organization (NATO) member states are said to have constructed a de facto decision-making system by establishing a networking system that is beyond the substantive control of each country's political branches: see David Held, Democracy and the Global Order: From the Modern State to Cosmopolitan Governance (Stanford: Stanford University Press, 1995) at 114. 
lectures indicates, ${ }^{10}$ Professor Jessup felt that the most important issue in transnational law was that of "choosing" rules from among the various relevant doctrines of national or international law available to those tasked with adjudicating a dispute. Likewise, Professor Koh describes a body of transnational law as a blend of domestic law and international law. ${ }^{11}$ Since the process of transnational law-making, as distinct from domestic and international law-making, has not been the subject of detailed analysis, it seems appropriate to turn to the nature of this process and analyze how public and private actors engage themselves in transnational law-making.

The sites and processes of international norm-making are diversifying along with the "economic and political expansion outward that characterizes industrialized states." ${ }^{12}$ In order to grasp the diversifying nature of transnational law-making it is therefore necessary to overcome the traditional state-centric understanding of the international law-making process and recognize the vital role that non-governmental actors play in transnational law-making. Transnational law can be classified into two subcategories that generally correspond to two different groups of participants in the law-making processes: "merchant law," arising out of the practice of business people in commercial transactions, and "cosmopolitan law," promoted by international officials or non-governmental organizations (NGOs). Some observers have pointed out that civil society organizations should be defined as non-profit NGOs for the purpose of distinguishing them from NGOs belonging to the business sector, such as the World Business Council. ${ }^{13}$ However, as corporate citizenship is now widely recognized, business people more readily associate themselves for public good and internalize codes of conduct on environmental or social issues into their business practices, regardless of legal regulation. ${ }^{14}$ Hence, there is little reason to distinguish organizations of civil society activists from those of business people striving to achieve corporate social responsibility.

Merchant law (lex mercatoria) is composed of customs made by business people in transnational transactions and the guidelines drafted and agreed to by business people to be sanctioned as law by the courts of relevant states or international arbitral tribunals. ${ }^{15}$ Merchant law is said to have developed at an accelerating pace during the last 50 years. ${ }^{16}$ The United Nations Convention on the Recognition and Enforcement of Foreign Arbitral Awards,${ }^{17}$ commonly known as the New York Convention, has facilitated the emergence of

Reproduced as chapter three, "The Choice of Law Governing the Problems” in Jessup, supra note 6 at 72-113.

See Harold Hongju Koh, “Transnational Public Law Litigation” (1991) 100 Yale L.J. 2347 at 2348-49. Ruti G. Teitel, “Humanity’s Law: Rule of Law for the New Global Politics” (2002) 35 Cornell Int'l L.J. 355 at 366.

See Martin Köhler, "From the National to the Cosmopolitan Public Sphere” in Daniele Archibugi, David Held \& Martin Köhler, eds., Re-Imagining Political Community: Studies in Cosmopolitan Democracy (Stanford: Stanford University Press, 1998) 231 at 232, n. 5.

See e.g. Guy Mundlak, "Industrial Citizenship, Social Citizenship, Corporate Citizenship: I Just Want My Wages” (2007) 8 Theor. Inq. L. 719 at 735-36.

For example, art. 1 of the Uniform Commercial Code stipulates that "Unless displaced by the particular provisions of this Act, the principles of law and equity, including law merchant ... [shall] supplement its provisions”: see U.C.C. § 1-103 (2005).

See Daniel C.K. Chow \& Thomas J. Schoenbaum, International Business Transactions: Problems, Cases, and Materials (New York: Aspen Publishers, 2005) at 30.

10 June 1958, 330 U.N.T.S. 3 (entered into force 7 June 1959). 
a new dimension of merchant law because awards are rendered by private lawyers in charge of arbitration and are therefore insulated from the influence of interstate politics. ${ }^{18}$ Some areas of merchant law are codified by NGOs of business people. For example, the International Chamber of Commerce, a private organization, published the International Commercial Terms (INCOTERMS) ${ }^{19}$ effectively establishing standard trade definitions that are now commonly used in international sales contracts. ${ }^{20}$ INCOTERMS is said to be one of the most successful examples of norms created by private actors. ${ }^{21}$ Creators of merchant law are business people, while each norm is recognized as an applicable law by the public authority's endorsement. ${ }^{22}$

Another form of law is cosmopolitan law. Although its significance was noted by Immanuel Kant in 1795, this is an area of law that has been neglected for almost 200 years. ${ }^{23}$ Cosmopolitan law can be best understood as the type of law that is made by "cosmopolitans," or those who are independent from particular states or business enterprises. Cosmopolitan law represents the interests of the global community as a whole. There are presently two types of cosmopolitans: international officials and members of NGOs. When an international organization is recognized as a legitimate institution for promoting universal interests, its officials can be said to be cosmopolitans as they are not obligated to seek or receive instructions from any authority external to the organization. For example, the UN is a quasiuniversal organization established by treaty for the purpose of maintaining international peace and security. ${ }^{24}$ Responsibilities of the Secretary-General and the staff of the UN are considered to be of an "international character," 25 so that the Secretariat is called the "First UN" and bears the image of a protector of global interests against the "Second UN," the General Assembly and the Security Council, which represent governmental interests. ${ }^{26}$ In turn, private persons acting as members of international NGOs may also be seen as cosmopolitans, provided that they advocate universal values, such as fundamental human rights.

See Alec Stone Sweet, “The New Lex Mercatoria and Transnational Governance” (2006) 13 Journal of European Public Policy 627 at 627-30.

19 International Chamber of Commerce, Incoterms 2000: ICC Official Rules for the Interpretation of Trade Terms (Paris: ICC Publishing, 1999).

20 More than 90 percent of the trade terms adopted in Japan are said to be the "Free on Board," "Cost and Freight," and "Cost, Insurance and Freight” stipulated in INCOTERMS: see Akira Kobayashi, Wagakuni de Shiyou sareru tamuzu no jishoteki Kenkyu [Empirical Research on Trade Terms Used in Japan] (Tokyo: Dobunkan-Syuppan, 1999) at 212 (in Japanese).

21 See Sandeep Gopalan, "A Demandeur-Centric Approach to Regime Design in Transnational Commercial Law” (2008) 39 Geo. J. Int’l L. 327 at 367.

22 See e.g. (2006) (Centro de Arbitraje de México), online: UNILEX <http://www.unilex.info/case.cfm? pid $=2 \& d o=$ case $\& i d=1149 \&$ step $=$ abstract $>$. Contra (2005) (Tribunale Padova), online: UNILEX $<$ http://www.unilex.info/case.cfm?pid=2\&do=case\&id=1004\&step=abstract $>$ (denying UNIDROIT as an applicable law and regarding it as incorporated in the relevant contract).

23 See infra note 27.

24 See e.g. Charter of the United Nations, 26 June 1945, Can. T.S. 1945 No. 7, art. 1(1).

25 See ibid., art. 100(2) (providing that the member states are obligated to respect the international character and refrain from seeking to influence them).

26 Inis L. Claude, Jr., "Peace and Security: Prospective Roles for the Two United Nations” (1996) 2 Global Governance 289 at 290-92. 
This article first explains the original concept of cosmopolitan law suggested by Kant. It then describes the emergence of de facto cosmopolitan law-making activities, several of which have led to the conclusion of a number of treaties and other governmental actions creating international norms. The article then discusses the two types of institutionalization of cosmopolitan law-making: a hybrid of international law-making and cosmopolitan lawmaking, and a purer version of cosmopolitan law-making. It then identifies two conditions for successful cosmopolitan law-making: the advisory or deliberative nature of cosmopolitan participation in law-making, and various safeguards for securing accountability. The article also discusses the proposed "Draft Charter of the East Asian Community" as an epochmaking proposal for regional integration in East Asia, focusing on its adoption of an idea of a hybrid of international law-making and cosmopolitan law-making.

\section{Two Aspects of Cosmopolitan LAw Advocated By IMMANUEL KanT}

In several of his well-known works, Kant emphasizes that there must be a third form of public law in addition to national and international law. He termed this third form "ius cosmopoliticum" (also known as Weltb gerrecht). ${ }^{27}$ According to Kant, cosmopolitan law is distinct from both domestic law and international law in that it is made by non-governmental actors rather than by governmental officials. Kant was worried that if governmental officials were allowed to monopolize the law-making authority, whether by way of legislation or through the conclusion of international treaties, they would conspire to look after their own interests at the sacrifice of the interests of ordinary citizens. ${ }^{28}$ Kant hoped that cosmopolitan law would promote universal hospitality among world citizens by securing the freedom of international movement of persons and free trade. ${ }^{29}$ He believed that cosmopolitan law should thus transcend national boundaries so that the rights and liberties of every individual would be guaranteed, regardless of where he or she was at a particular time.

Some scholars have focused on the substantive aspect of cosmopolitan law in their quest for a "higher law" that trumps any inconsistent rule of national or international law..$^{30}$ However, if cosmopolitan law is to be defined by the fact that its inherent values are superior to other forms of positive law, then the concept may, depending on how it is interpreted, well be criticized for its tendency to fall into false universalism. ${ }^{31}$ Moreover, when the concept of cosmopolitan law centres on its substantive components, a delicate question about its procedural aspects comes to the surface: by whom and by what kind of process can the content of cosmopolitan law be recognized? In other words, what specifically is the appropriate mechanism for creating cosmopolitan law, keeping in mind that the rules of

See Immanuel Kant, “Toward Perpetual Peace” in Mary J. Gregor, ed. and trans., Practical Philosophy (Cambridge: Cambridge University Press, 1996) 311 at 322.

See James Bohman \& Matthias Lutz-Bachmann, “Introduction” in James Bohman \& Matthias LutzBachmann, eds., Perpetual Peace: Essays on Kant’s Cosmopolitan Ideal (Cambridge: MIT Press, 1997) 1 at 7.

See Immanuel Kant, “The Metaphysics of Morals” in Gregor, supra note 27, 353 at 489-90. See also Fernando R. Tesón, “The Kantian Theory of International Law (1992) 92 Colum. L. Rev. 53 at 76, 86. See Noah Feldman, “Cosmopolitan Law?” (2007) 116 Yale L.J. 1022 and Mark Weston Janis, “The Quest for a Higher Law” (2007) 116 Yale L.J. Pocket Part 317 at 320 (describing Noah Feldman’s "cosmopolitan law," which focuses on its substance rather than its sources, as a quest for a higher law). See Jessica Stern, “The Dangers and Demands of Cosmopolitan Law” (2007) 116 Yale L.J. Pocket Part 322 at $324,326$. 
treaty law, as found in art. 53 of the Vienna Convention on the Law of Treaties, define "peremptory norms" on the basis of positive acceptance and recognition by "the international community of States as a whole,” rather than by their inherent virtues. ${ }^{32}$

Kant left this question unanswered. His vision of cosmopolitan law is thus criticized for

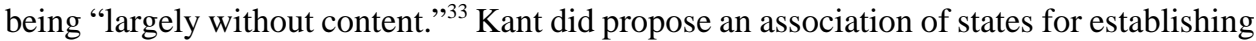
perpetual peace, ${ }^{34}$ but he made no mention of a secretariat that would be responsible for managing the association and realizing its collective interests vis-à-vis the interests of individual member states. ${ }^{35}$ Kant also appears to have expected the various kings and queens of Europe to accept the advice of philosophers and to endorse the making of cosmopolitan law, ${ }^{36}$ believing in a "world of readers" (also known as Gelehrtenrepublik) where the publications of philosophers would provide the supreme guidelines for the nation. ${ }^{37}$ Kant appears to have attached great importance to the free movement of persons and goods because he was pinning his hopes on public opinion led by philosophers rushing from country to country. It is said that rules have indeed emerged out of de facto communication, the most suitable examples of which are transnational mutual recognition regimes. ${ }^{38}$ Nevertheless, they have come into existence mainly through the propagation of merchants and enlightened citizens, instead of philosophers.

Kant's reliance on public opinion has many implications for today, subject to certain modifications. However, it remains necessary to find an alternative mechanism to produce the required sound public opinion or, more accurately put in the term coined by Jeremy Bentham, "public sanction," 39 in light of the differences between the social situation in the days of Kant and that of the twenty-first century where the electronic media has enormous influence. ${ }^{40}$ However, just as Kant revived the concept of cosmopolitan law used by the Stoic philosophers of ancient Greece ${ }^{41}$ by adapting it to the conditions of the Westphalian system of states, it may be a fruitful endeavour to develop this concept to suit the age of

23 May 1969, 1155 U.N.T.S. 331, art. 53 (entered into force 27 January 1980) [emphasis added]. Harry D. Gould, “Toward a Kantian International Law” (1999) 5 Int’l L. Theory 31 at 33.

See Kant, “Toward Perpetual Peace,” supra note 27 at 325-28.

See Mortimer Sellers, “The Kantian Theory of Public International Law” (1999) 5 Int’l L. Theory 43 at 49, 51 (pointing out that the "lack of specificity about the structures needed to secure and preserve a lawful republican state” is the greatest weakness in Kant's argument).

See Kant, “Toward Perpetual Peace,” supra note 27 at 337-38.

See Immanuel Kant, “An Answer to the Question: What is Enlightenment?” in Gregor, supra note 27,11 at 18 (stating that "by the public use of one's own reason I understand that use which someone makes of it as a scholar before the entire public of the world of readers”).

See Kalypso Nicolaidis \& Gregory Shaffer, “Transnational Mutual Recognition Regimes: Governance Without Global Government” (2005) 68:3 Law \& Contemp. Probs. 263 at 266, 299.

Jeremy Bentham, “An Introduction to the Principles of Morals and Legislation” in Wilfrid Harrison, ed., A Fragment on Government and An Introduction to the Principles of Morals and Legislation (Oxford: Basil Blackwell,1948) 113 at 148, n.1 (arguing that no opinion will function politically unless it invokes physical sanction by the public).

See James Bohman, “The Public Spheres of the World Citizen” in Bohman \& Lutz-Bachmann, supra note 28,179 at 196 .

With regard to the Stoic conception of cosmopolitanism, see Martha C. Nussbaum, "Patriotism and Cosmopolitanism” in Joshua Cohen, ed., For Love of Country: Debating the Limits of Patriotism (Boston: Beacon Press, 1996) 2 at 6-7 (finding the uniqueness of the Stoics in the shift of the internal perspective away from a particular polis to the world at large). 
globalization. ${ }^{42}$ Studying the original meaning of a concept used by a philosopher is one thing and developing the concept to utilize it in a different time and social context is another. Both have their merits.

\section{EMERGENCE OF DE FACTO COSMOPOLITAN LAW-MAKING}

A kind of cosmopolitan law-making, slightly different from what Kant expected, has finally emerged as a result of what is known as the "global 'associational revolution,","43 that is, the proliferation of a massive array of self-governing private organizations, not dedicated to distributing profits to shareholders or directors, pursuing public purposes outside the formal apparatus of the state. De facto cosmopolitan law-making, or cosmopolitan lawmaking through non-institutionalized activities, has gradually gained force since it started on a large scale in the mid-twentieth century. International officials and NGOs, dedicated to the establishment of the rule of law throughout the global community, now participate in efforts of cosmopolitan law-making through such activities as consciousness-raising by resorting to media campaigns. ${ }^{44}$ More than that, they often play the role of a "norm entrepreneur" ${ }^{45}$ by contriving proposals in treaty-making processes or even drafting treaties that states were not willing to make. In such cases, the resulting treaties should be called, in form, international law because they are agreements of governments or intergovernmental organizations. However, they are outcomes of law-making processes in which cosmopolitans played an indispensable role to the extent that the main points of the treaties were substantially designed by them.

For example, in 1992, the International Association of Lawyers Against Nuclear Arms, an NGO that had been involved in the anti-nuclear weapon movement, decided to establish a network called the "World Court Project" in order to break the deadlock of intergovernmental negotiations over the issue of nuclear disarmament. ${ }^{46}$ They succeeded in cultivating like-minded states and, finally, moving the UN General Assembly to adopt a resolution requesting the International Court of Justice to issue an advisory opinion on the legality of the use or the threat of nuclear weapons. ${ }^{47}$ The members of these organizations supported the preparation of the written and oral pleadings for like-minded states and a few

42 Fernando R. Tesón, “Kantian International Liberalism” in David R. Mapel \& Terry Nardin, eds., International Society: Diverse Ethical Perspectives (Princeton: Princeton University Press, 1998) 103 at 103.

43 This term was coined by Dr. Lester M. Salamon of Johns Hopkins University: see Lester M. Salamon, “The Rise of the Nonprofit Sector" (1994) 73 Foreign Affairs 109 at 109 (pointing out that the “associational revolution” may be permanently altering the relationship between states and citizens and "prove to be as significant to the latter twentieth century as the rise of the nation-state was to the latter nineteenth").

44 Some went so far as to recognize practices of non-governmental actors as an element for establishing a rule of customary international law, although such an argument is not widely supported: see Statement of Professor Myres Smith McDougal in The American Law Institute, 57th Annual Meeting, The American Law Institute Proceedings 1980 (Philadelphia: The American Law Institute, 1981) at 65.

45 This term was coined and developed by Professor Cass R. Sunstein of the University of Chicago: see Cass R. Sunstein, "Social Norms and Social Roles” (1996) 96 Colum. L. Rev. 903 at 909 (defining "norm entrepreneurs" as "people interested in changing social norms" in order to exploit the fragility of these norms and bring "norm bandwagons and norm cascades” for changing social conditions). “World Court Project,” online: Lawyers’ Committee on Nuclear Policy <http://lcnp.org/wcourt>. General and Complete Disarmament, GA Res. 49/75(K), UN GAOR, 49th Sess., UN Doc. A/RES/49/75 (1995). 
members were even appointed to serve as consultants for states making oral arguments before the Court. ${ }^{48}$ Although the organizations were not permitted to submit amicus briefs in this case ${ }^{49}$ some of them donated documents on the damage that the Hiroshima and Nagasaki atomic bombings had caused to the library of the Peace Palace. ${ }^{50}$ Although Judge Oda insisted on declining their request, criticizing the involvement of NGOs in the formation of the General Assembly resolution requesting the advisory opinion, ${ }^{51}$ the other 13 judges did not concur with him in this regard and decided to comply with the request. ${ }^{52}$ The Court declared unanimously, in particular, the "obligation to pursue in good faith and bring to a conclusion negotiations leading to nuclear disarmament in all its aspects under strict and effective international control." 53 This conclusion is said to be "innovative"54 in that it acknowledged an obligation exceeding that under the pacta de contrahendo, a clause that obligates the parties to negotiate in good faith and leaves the conclusion of the negotiation in their hands, such as art. VI of the Treaty on the Non-Proliferation of Nuclear Weapons. ${ }^{55}$ The General Assembly took note of the opinion and called upon all states to fulfill the said obligation. $^{56}$

For example, a number of university professors made oral presentations as delegates of Samoa and Solomon Islands: see Legality of the Threat or Use of Nuclear Weapons, Advisory Opinion, [1996] I.C.J. Rep. 226 at 231. These governments would have faced difficulty if these professors had not prepared the pleadings free of charge or with nominal fees. Hence, it seems that the initiative to construct the pleadings resided with these professors rather than the governmental officials of these states.

The Court accepted only one amicus brief in its history: see International Status of South West Africa, “Correspondence from the Registar to Mr. Robert Delson, League for the Rights of Man” (16 March 1950), [1950] I.C.J. Pleadings 327. The registrar of the Court, not in his official capacity, had once suggested that the Court would be unwilling to "open the floodgates": see Legal Consequences for States of the Continued Presence of South Africa in Nambia (South West Africa) notwithstanding Security Council Resolution 276, “Correspondence from the Registrar to Professor Reisman" (6 November 1970), [1971] I.C.J. Pleadings 638 at 639. In fact, about 1,200 “applications” were sent to the Court by private persons in the fiscal year 1995-1996: see "Applications From Private Persons" in Yearbook of the International Court of Justice 1995-1996, vol. 50 (The Hague: International Court of Justice, 1996) at 256.

See Masaki Ikeda \& Osamu Niikura, “Kaku-Heiki Wa Dou Sabakareta Ka [How Nuclear Weapons Are Judged]" (1996) 627 Sekai 143 at 149 (in Japanese). Legality of the Threat or Use of Nuclear Weapons, Dissenting Opinion of Judge Oda, [1996] I.C.J. Rep. 330 at 367-68.

$52 \quad$ Legality of the Threat or Use of Nuclear Weapons, Advisory Opinion, supra note 48 at 265. Judge Guillaume, while agreeing with the majority, appended an opinion for expressing his hope that governments and intergovernmental institutions would retain "sufficient independence of decision" to resist the "powerful pressure groups which besiege them today with the support of the mass media": see Legality of the Threat or Use of Nuclear Weapons, Separate Opinion of Judge Guillaume, [1996] I.C.J. Rep. 287 at 288.

$53 \quad$ See Legality of Threat or Use of Nuclear Weapons, Advisory Opinion, ibid. at 267.

$54 \quad$ Hisakazu Fujita, "The Advisory Opinion of the International Court of Justice on the Legality of Nuclear Weapons” (1997) 316 Int'l Rev. Red Cross 56 at 63-64.

55 Treaty on the Non-Proliferation of Nuclear Weapons, 1 July 1968, 729 U.N.T.S. 168, art. 6 (entered into force 5 March 1970).

56 See Advisory Opinion of the International Court of Justice on the Legality of the Threat or Use of Nuclear Weapons, GA Res. 51/45(M), UN GAOR, 51st Sess., UN Doc. A/RES/51/45 (1997). The General Assembly adopted three resolutions to follow up on the opinion: Advisory Opinion of the International Court of Justice on the Legality of the Threat or Use of Nuclear Weapons, GA Res. 52/38(O), UN GAOR, 52d Sess., UN Doc. A/RES/52/38 (1998), Follow-up to the Advisory Opinion of the International Court of Justice on the Legality of the Threat or Use of Nuclear Weapons, GA Res. 53/77(W), UN GAOR, 53rd Sess., UN Doc. A/RES/53/77 (1999); Follow-up to the Advisory Opinion of the International Court of Justice on the Legality of the Threat or Use of Nuclear Weapons, GA Res. 54/54(Q), UN GAOR, 54th Sess., UN Doc. A/RES/54/54 (2000). 
Another example of cosmopolitan law-making in action is the "Ottawa Process," which was promoted by the International Campaign to Ban Landmines, a growing network that as of the end of 1997 was comprised of more than 1,000 NGOs from more than 60 states, including like-minded states such as Austria and Canada. ${ }^{57}$ The Ottawa Process concluded with the adoption of the Convention on the Prohibition of the Use, Stockpiling, Production and Transfer of Anti-Personnel Mines and on their Destruction, ${ }^{58}$ signed by 121 countries at Ottawa on 3 December 1997, and entered into force on 1 March 1999. It is said that the “"Shadow' meetings and briefings, held by NGOs in the UN buildings concurrently with the [Convention on Prohibitions or Restrictions on the Use of Certain Conventional Weapons which may be deemed to be Excessively Injurious or to have Indiscriminate Effects ${ }^{59}$ ] official delegates meetings, proved to be the incubators for the [Ottawa Process]. ${ }^{60}$ Preparing for the formal process, the NGOs played an educational role by resorting to media, including comics, in order to strengthen the nascent norm against landmines ${ }^{61}$ as well as performing the "name and shame" function. ${ }^{62}$ Under the Ottawa Process, the International Campaign to Ban Landmines and the International Committee of the Red Cross were invited to meetings and played an important part in the development of the text of the treaty. ${ }^{63}$ This invitation demonstrates the trend, though ad hoc, towards formal involvement of NGOs in the international law-making process. ${ }^{64}$ Universalization of the treaties remains to be realized, however, because a few states, including China, Russia, and the United States, which possess target weapons, have not signed or ratified the treaties. ${ }^{65}$ This process of treaty-making was followed by the "Oslo Process," which began in 2007 and resulted in the adoption of the Convention on Cluster Munitions. ${ }^{66}$

See Jody Williams, "Nobel Lecture” (Oslo, 10 December 1997), online: The Nobel Foundation <http://nobelprize.org/nobel_prizes/ peace/laureates/1997/williams-lecture.html>.

18 September 1997, 2056 U.N.T.S. 211 (entered into force 1 March 1999).

10 October 1980, 1342 U.N.T.S. 137 (entered into force 2 December 1983).

See Virgil Wiebe, "Footprints of Death: Cluster Bombs as Indiscriminate Weapons Under International Humanitarian Law” (2000) 22 Mich. J. Int’l L. 85 at 159, n. 335.

See Lesley Wexler, "The International Deployment of Shame, Second-Best Responses, and Norm Entrepreneurship: The Campaign to Ban Landmines and the Landmine Ban Treaty” (2003) 20 Ariz. J. Int'l \& Comp. L. 561 at 569-72.

See ibid. at 572-76.

See Jody Williams \& Stephen Goose, “The International Campaign to Ban Landmines” in Maxwell A. Cameron, Robert J. Lawson \& Brian W. Tomlin, eds., To Walk Without Fear: The Global Movement to Ban Landmines (Toronto: Oxford University Press, 1998) 20 at 43.

See John King Gamble \& Charlotte Ku, "International Law - New Actors and New Technologies: Center Stage for NGOs?” (2000) 31 Law \& Pol’y Int’l Bus. 221 at 236-37.

See e.g. Shawn Roberts, “No Exceptions, No Reservations, No Loopholes: The Campaign for the 1997 Convention on the Prohibition of the Development, Production, Stockpiling, Transfer, and Use of AntiPersonnel Mines and on Their Destruction” (1998) 9 Colo. J. Int'l Envtl. L. \& Pol'y 371 at 390-91. 30 May 2008, online: United Nations <http://treaties.un.org/doc/Publication/CTC/26-6.pdf>. For example, the aim of the establishment of the Cluster Munition Coalition, a network of 150 NGOs, was to serve a similar role as the International Campaign to Ban Landmines had done in the landmines campaign: see Bonnie Docherty, "The Time Is Now: A Historical Argument for a Cluster Munitions Convention” (2007) 20 Harv. Hum. Rts. J. 53 at 64-66. 
Aside from such law-making activities, NGOs can also contribute to another form of normative development, namely the creation of so-called "soft law." Soft law is a norm that indicates the trend in customary international law-making but that cannot be relied upon as a rule of law by judges or arbitrators in a lawsuit. ${ }^{67}$ For example, a non-governmental multistakeholder consultation forum has succeeded in creating guidelines and a monitoring mechanism in a subject area in which progress through the process of treaty-making would have been much more difficult. ${ }^{68}$ Activities of the Global Reporting Initiative (GRI), ${ }^{69}$ a multi-stakeholder organization publishing standardized protocols for reporting on the economic, environmental, and social dimensions of corporate activities, including human rights indicators, cannot be characterized as an index of law-making because these guidelines are not formally recognized as law by national or international courts. However, they may lead to norm creation as they are accepted as righteous and adopted by a number of private companies. ${ }^{70}$ Their importance may be found in the fact that the UN Global Compact has agreed to accept corporate reports meeting the GRI guidelines as legitimate documents under its procedure. ${ }^{71}$ Reports by these companies will be monitored by interested NGOs and may trigger public sanction.

It is worth mentioning that what we call soft law is often the result of a process where NGOs and persons holding governmental offices but acting in private capacities prepare a report to initiate a proposed set of guidelines. Joseph Montville, a diplomat with experience in the Near Eastern and South Asian Bureau of the Department of State, emphasized the usefulness of such a process and named it "track-two" diplomacy. ${ }^{72}$ A track-two process may be distinguished from a "track-one" process where the participants are solely composed of governmental officials, and a "track-three” process where the participants are all private persons external to the official law-making process. ${ }^{73}$ By enabling governmental officials to exchange their candid opinions with others and including a broad range of stakeholders into the negotiations, track-two processes provide governments with flexible political channels that may be useful when taking steps towards the resolution of a politically sensitive problem. ${ }^{74}$ For example, the Asia-Pacific Economic Cooperation Conference (APEC) was established largely as a result of the efforts of the Pacific Economic Cooperation Council

72 Joseph V. Montville, "Transnationalism and the Role of Track-two Diplomacy” in W. Scott Thompson \& Kenneth M. Jensen, eds., Approaches to Peace: An Intellectual Map (Washington, D.C.: United States Institute of Peace, 1992) 253 at 263.

73 For a description of various functions of track-two diplomacy, see Timothy L. Fort \& Cindy A. Schipani, "An Action Plan for the Role of Business in Fostering Peace” (2007) 44 Am. Bus. L.J. 359 at 367-68. See Jennifer Oetzel, Kathleen A. Getz \& Stephen Ladek, "The Role of Multinational Enterprises in Responding to Violent Conflict: A Conceptual Model and Framework for Research” (2007) 44 Am. Bus. L.J. 331 at 334 
(PECC). ${ }^{75}$ The PECC is a track-two forum that consists of scholars, business people, and governmental officials (serving in their private capacities) from 25 countries and "entities" such as Chinese-Taipei. The APEC preserves the traditional character of public-private mixture by recognizing the PECC as a formal observer at the APEC ministers' meetings. APEC meetings regularly take note of the study reports published by the PECC task forces. For example, in 1994 the APEC ministerial meeting recommended the adoption of the Asia Pacific Investment Code, which was based on a PECC draft code. ${ }^{76}$ It may be said that the PECC is not only observing the APEC meetings, but also participating in its policy-making or even drafting critical decisions by APEC.

\section{INSTITUTIONALIZATION OF COSMOPOLITAN LAW-MAKING: THE EUROPEAN UNION AS THE MOST ADVANCED FORM}

Along with the de facto participation of NGOs in international law-making, there is an institutional mechanism for cosmopolitan law-making now emerging globally as well as through regional international frameworks. ${ }^{77}$ At present, the European Union (EU) offers the most advanced institutional framework for engaging in cosmopolitan law-making. According to Professor Martti Koskenniemi of the University of Helsinki, the EU might be understood as the greatest success of "the fourth tradition of legal cosmopolitanism," which represents the reconciliation of the civilizing sensibility of the late nineteenth century with pragmatism in an era of cold war. ${ }^{78}$ It is true that the right to withdraw from the EU, which has been recognized tacitly, is now clearly stipulated in the Treaty of Lisbon amending the Treaty on European Union and the Treaty establishing the European Community. ${ }^{79}$ Therefore, states retain the sovereign prerogatives to free themselves from EU laws and it follows that the lawmaking institution of the EU is ultimately dependent on the will of its member states. However, as long as a state remains a member of the EU, it is obligated to accept the outcomes of the law-making mechanism of the EU as legitimate. This mechanism includes

75 See David K. Linnan, “APEC Quo Vadis” (1995) 89 A.J.I.L. 824 at 825. Other intergovernmental fora in East Asia also co-operate closely with track-two processes: the Association of Southeast Asian Nations (ASEAN) Regional Forum (ARF) with the Council for Security Cooperation in the Asia-Pacific (CSCAP), see “About Us,” online: CSCAP <http://www.cscap.org/index.php?page=about-us> and the Asia-Europe Meeting (ASEM) with the Council for Asia-Europe Cooperation (CAEC), see online: Asia New Zealand Foundation <http://www.asianz.org/our-work/track-2/track-2-directory/council-asiaeurope-cooperation-caec $>$.

$76 \quad$ See Linnan, ibid. at 830, n. 27.

77 Examples of global institutions for cosmopolitan law-making include the Kimberley Process Certification Scheme. The structure of this process is said to be unique because the NGOs, such as the World Diamond Council, serve equally with participant nations on several of the working groups: see Ann C. Wallis, "Data Mining: Lessons from the Kimberley Process for the United Nations' Development of Human Rights Norms for Transnational Corporations” (2005) 4 Northwestern Journal of International Human Rights 388 at 397.

78 See Martti Koskenniemi, “On the Idea and Practice for Universal History with a Cosmopolitan Purpose” in Bindu Puri \& Heiko Sievers, eds., Terror, Peace, and Universalism: Essays on the Philosophy of Immanuel Kant (New Delhi: Oxford University Press, 2007) 122 at 133.

7913 December 2007, [2007] O.J. C 306/01, art. 1(58) [Lisbon Treaty]. The Lisbon Treaty replaces the rejected Treaty Establishing a Constitution for Europe, 16 December 2004, [2004] O.J. C 310/01. The Lisbon Treaty is expected to be ratified by all the member states. It is pointed out that the provision enables the EU “to evolve by contraction as well as expansion”: see Stephen C. Sieberson, “The Treaty of Lisbon and Its Impact on the European Union's Democratic Deficit” (2008) 14 Colum. J. Eur. L. 445 at 452 . 
two types of cosmopolitan law-making: a hybrid of international law-making and cosmopolitan law-making, and a pure form of cosmopolitan law-making.

According to arts. 211, 251, and 252 of the Treaty Establishing the European Community, ${ }^{80}$ the European Commission has, in general, the legal power to initiate legislation sua sponte or with the suggestion of the Council of the European Union. ${ }^{81}$ The members of the European Commission are international officials who are completely independent of the state of their nationality in the performance of their duties and are obligated to give solemn assurances that they will respect the obligations arising from their duties, ${ }^{82}$ while the Council of the European Union consists of ministers from the various member states. ${ }^{83}$ This power of initiation indicates that the European Commission serves as a conduit for a form of cosmopolitan law-making. Likewise, the European Parliament, whose members are directly elected by the populace, ${ }^{84}$ is vested with the authority to approve most bills of importance. ${ }^{85}$ The regulations, directives, and decisions made in such a process can be considered to be a hybrid of cosmopolitan law and international law, because they are made in a collective process of law-making in which non-governmental institutions are entrusted with a necessary role. The governmental representatives retain the decisive power, while the international officials and the representatives of the European citizens are formally recognized as participants in the legal process and conferred with the power necessary to initiate a bill. ${ }^{86}$ These regulations can be applicable directly to private persons in the member states. ${ }^{87}$

In addition, art. 211 of the Treaty Establishing the European Community and the decisions by the Council based on art. 202 of the Treaty bestow on the European Commission the decisive power to issue regulations on specified matters. This can be viewed as a system designed to develop pure cosmopolitan law because the lawmakers are international officials and nobody else. Of course, the European Commission should act intra vires and keep close consultation with representatives of the member states before issuing directives through the Committee of Permanent Representatives (COREPER) ${ }^{88}$ so that, in reality, the member states are able to influence the decisions of the Commission to a certain extent. ${ }^{89}$ However, the consent of the majority of the member states is not required as a matter of law before the commission can publish regulations. The influence of the member states upon the Commission remains purely political. So far, the EU offers the only example of pure cosmopolitan law in contrast to the more numerous examples of a hybrid of international law and cosmopolitan law.

24 December 2002, [2002] O.J. C 325/33.

With regard to the law-making acts of the political organs of the EU, see generally K.P.E. Lasok, Law \& Institutions of the European Union, 7th ed. (London: Butterworths, 2001) at 133-57.

Treaty Establishing the European Community, supra note 80, art. 213(2).

Ibid., art. 203.

Ibid., art. 189.

Ibid., arts. 192, 251-52.

The structure of the EU is called a "mixed constitution": see Neil MacCormick, Questioning Sovereignty: Law, State and Nation in the European Commonwealth (Oxford: Oxford University Press, 1999) at 148-49, 156.

Treaty Establishing the European Community, supra note 80, art. 249.

Ibid., art. 207(1).

See Francesca Bignami, “Transgovernmental Networks vs. Democracy: The Case of the European Information Privacy Network” (2005) 26 Mich. J. Int’l L. 807 at 839. 


\section{CONDITIONS FOR COSMOPOLITAN LAW-MAKING: AdVISORY CHARACTER AND ACCOUNTABILITY}

Unlike governmental officials, cosmopolitans are not elected or appointed by a formal procedure in accordance with law. Thus, stakeholders might not recognize the self-appointed cosmopolitans as legitimate representatives of the public good in the law-making process. When a government is captured by the views of unelected NGOs that oppose values held by a majority of people within a nation, cosmopolitan law can even be misused by extremists as a means to undermine the constitutional government of individual states. ${ }^{90}$ It is also clear that, as the distance grows between ordinary citizens and global political centers where political elites co-operate and compete with each other, voices of local communities and their citizens tend to be ignored. ${ }^{91}$ Moreover, governments often exploit cosmopolitan participation as a political "fig leaf” by hiring consulting companies and think tanks closely affiliated with them; it cannot be denied that making good use of private intellectual resources has its merits. The NGOs themselves may make use of these processes as public relations exercises. Thus, there is a danger that cosmopolitan law-making, when not properly monitored, will lead to "cosmocracy,"92 that is, a kind of despotism by political elites of the member states and international bureaucrats. A democratic deficit is inherent in such a process of cosmopolitan law-making.

In order to prevent these dangers and to further promote productive cosmopolitan lawmaking, the process must be constructed in such a way that two preconditions are met. First, NGOs should only be admitted to participate in the consultation or discussion aspects of the policy-making or monitoring process, and should not be vested with decision-making authority. ${ }^{93}$ The institutionalization of cosmopolitan law-making works best when it follows the principle of "voice, not vote," that is, allowing as many cosmopolitans as possible to input voices of under-represented stakeholders while retaining the formal power to make decisions in the hands of public authority.$^{94}$ In other words, participatory democracy that enables a silent majority or minority to present their views into the deliberative processes is required as well as representative democracy. ${ }^{95}$

Second, cosmopolitans themselves should make sure that they are accountable to all of the relevant stakeholders and that the process of law-making is transparent to the general public. For example, NGOs may publish a code of conduct for themselves and assess each others'

See Jeremy A. Rabkin, Law Without Nations?: Why Constitutional Government Requires Sovereign States (Princeton: Princeton University Press, 2005) at 24-25, 236-37, 248.

91 See Perez, supra note 68 at 23 (pointing out that there is a risk to individual freedom and cultural pluralism when a strong political center is established).

Anthony McGrew, "Power Shift: From National Government to Global Governance?” in David Held, ed., A Globalizing World?: Culture, Economics, Politics, 2d ed. (London: Routledge, 2004) 127 at 153 (focusing on a specific power site in today's global politics). Compare John Keane, Global Civil Society? (Cambridge: Cambridge University Press, 2003) at 97-98 (using the same term as an ideal type having broader meaning: a world polity based on worldwide webs of interdependence). See Mary Kaldor, Global Civil Society: An Answer to War (Cambridge, U.K.: Polity Press, 2003) at 107108.

94 See Michael Edwards, NGO Rights and Responsibilities: A New Deal for Global Governance (London: Foreign Policy Center, 2000) at 29-30.

95 See Panel of Eminent Persons on United Nations-Civil Society Relations, We the Peoples: Civil Society, the United Nations and Global Governance, UN GAOR, 58th Sess., UN Doc. A/58/817 (2004). 
performance by issuing certifications for those who conform to it. For example, it is said that the Philippine Council for NGO Certification is the most outstanding and fully developed examples of NGO self-regulation. ${ }^{96}$ The Council, established in 1998, is recognized as an institution that accredits NGOs applying for donee status when they meet the minimum standards for certification in six categories: vision, mission, and goals; governance; administration; program operations; financial management; and networking. ${ }^{97}$ As of February 2007, it has evaluated 941 organizations and certified $748,{ }^{98}$ while denying status or remanding for completion in 193 cases.

In addition, an NGO may watch other NGOs and rate them according to its own criteria. For example, in 2003 the American Enterprise Institute, collaborating with the Federalist Society for Law and Public Policy Studies, initiated the NGO Watch Project as a means to of monitoring NGOs. The NGO Watch Project has since been reorganized and renamed the Global Governance Watch. ${ }^{99}$ Some scholars welcomed the launch of the NGO Watch Project as a useful initiative to establish a mutual monitoring system by NGOs. ${ }^{100}$ However, it also triggered strong opposition from human rights NGOs because the project was thought of as a cover for political attacks against liberal groups by neo-conservative groups. ${ }^{101}$

If employing a private rating system by an NGO against other NGOs’ activities may not be particularly useful and do more harm than good, it seems better to have an international institution incorporating NGOs into its formal law-making process and supervising them within the institution. Governmental representatives and cosmopolitans should take measures to check each other within such institutions. ${ }^{102}$ The institutions, in turn, must set out clear criteria and procedures for selecting NGOs and build partnerships with them so that the resources of the institutions will be effectively used. ${ }^{103}$ The beneficiaries of such a new legal system will ultimately be the citizens of the global community.

See Lisa Jordan \& Peter van Tuijl, "Rights and Responsibilities in the Political Landscape of NGO Accountability: Introduction and Overview” in Lisa Jordan \& Peter van Tuijl, eds., NGO Accountability: Politics, Principles and Innovations (London: Earthscan, 2006) 3 at 15. Philipine Council for NGO Certification (PCNC), "PCNC: Background and Rationale,” online: PCNC $<$ http://www.pcnc.com.ph/background.php>.

"Accountability in Practice: Philippine Council for NGO Certification (PCNC)" Accountability in Action Newsletter (March 2007), online: One World Trust <http://www.oneworldtrust.org/index. php?option=com_docman\&task=cat_view\&gid=768Itemid=55>.

See online: Global Governance Watch <http://www.globalgovernancewatch.org/>. Similar organizations have been established since then. For example, the NGO Monitor aims at "promoting critical debate and accountability of human rights NGOs in the Arab Israeli conflict": see online: NGO Monitor $<$ http://www.ngo-monitor.org>.

See Steve Charnovitz, “Accountability of Non-Governmental Organizations in Global Governance” in Jordan \& van Tuijl, supra note 96, 21 at 38.

Robert Charles Blitt, "Who Will Watch the Watchdogs?: Human Rights Nongovernmental Organizations and the Case for Regulation” (2004) 10 Buff. H.R.L. Rev. 261 at 263, n. 10.

Michael Edwards, "Foreword" in Jordan \& van Tuijl, supra note 96, vii at viii (pointing out that the NGO Watch Project seemed to aim at closing off the liberal groups' access to influence and resources, rather than improving their performance).

Panel of Eminent Persons on United Nations-Civil Society Relations, supra note 95 at 27-28. 


\section{THE “DRAFT CHARTER OF THE EAST ASIAN COMMUNITY”: AN EXAMPLE OF A PROPOSAL FOR ESTABLISHING AN INSTITUTION OF COSMOPOLITAN LAW-MAKING}

In today's closely correlated and interdependent world, cosmopolitan law plays an increasingly important role. A number of proposals have recently been made to empower existing international organizations to be involved in a hybrid of international and cosmopolitan law-making. Examples of large-scale proposals include one for establishing a peoples' assembly in the UN in addition to the existing General Assembly. Professor Jürgen Habermas of Frankfurt University suggests that, if the peoples' assembly is established, it will function like the U.S. House of Representatives while the General Assembly will be like the U.S. Senate. ${ }^{104}$ However, the analogy with Congress is misleading because it is generally agreed that the peoples' assembly should be an advisory body, at least in its beginning. ${ }^{105}$ Another example is a proposal to amend the Statute of the International Court of Justice in order to confer upon the Court, composed of 15 independent judges, compulsory jurisdiction. ${ }^{106}$ If this proposal were be adopted, the Court would be much more actively involved in case law, a sort of pure cosmopolitan law.

Among these proposals for establishing or strengthening an institution of cosmopolitan law-making, it is particularly noteworthy that the "Draft Charter of the East Asian Community" has been published. ${ }^{107}$ The Draft Charter is a product of collaboration among scholars who gathered from different parts of the region and joined the Comparative Regionalism Project (CREP) organized by the Institute of Social Science at the University of Tokyo. The Draft Charter has been published in English and Japanese and is going to be translated into Korean. ${ }^{108}$ It is becoming a focal point of the discussion on community building in East Asia. If adopted, the Draft Charter will create a community consisting of "ASEAN plus three” states, namely the ten member states of the Association of Southeast

See Jürgen Habermas, "Kant’s Idea of Perpetual Peace, with the Benefit of Two Hundred Years' Hindsight" in Bohman \& Lutz-Bachmann, supra note 28, 113 at 134. For a thorough study of the Global Peoples' Assembly, see Richard Falk \& Andrew Strauss, “On the Creation of a Global Peoples Assembly: Legitimacy and the Power of Popular Sovereignty” (2000) 36 Stan. J. Int’l L. 191.

Andrew Strauss, "On the First Branch of Global Governance” (2007) 13 Widener Law Review 347 at 348-50.

106 See Daniele Archibugi, "From the United Nations to Cosmopolitan Democracy” in Daniele Archibugi \& David Held, eds., Cosmopolitan Democracy: An Agenda for a New World Order (Cambridge, U.K.: Polity Press, 1995) 121 at 146-47. But see Thomas M. Franck, Judging the World Court (New York: Priority Press Publications, 1986) at 68 ("If the world is not ready for world government, it is certainly not ready for a world government by fifteen jurists"). Asian Regionalism from a Legal Perspective (London: Routledge, 2009) at 256 [Draft Charter]. 
Asian Nations (ASEAN) ${ }^{109}$ plus the People's Republic of China, Japan, and Korea. ${ }^{110}$ In 2007, these states endorsed a report of the East Asia Study Group (EASG), ${ }^{111}$ a track-one group that was conducting research activities along the lines suggested by an earlier report published by the East Asian Vision Group (EAVG), ${ }^{112}$ a track-two group with participants from the same 13 states. The reports of the EAVG and the EASG focused mainly on an agenda for each policy area and left the design of the institutional framework of the future community open. Against this background, the Draft Charter has its particularities in proposing a concrete plan for institutional and procedural legalization as a first step in the process of community building, readjusting the inconsistent "acquis" of the "ASEAN plus three” activities.

The Draft Charter aims to "promote peace, security, stability, a higher standard and better quality of living, and equitable prosperity of the peoples of the region." "East Asia is the only region where there remains a kind of "cold war" structure because a few countries are still commited to communism. Besides, peoples in the region remember the history of aggression by two empires, that is, the Chinese and Japanese empires and the reconciliation that is currently under way. The East Asian Community is an endeavour to establish an information centre of the region for facilitating communications among stakeholders to the point where interdependence becomes so deep that member states may not exit from the Community.

The Draft Charter proposes the establishment of five main institutions for the Community. The East Asian Council ${ }^{114}$ and the Council of Ministers ${ }^{115}$ are essentially intergovernmental

On 20 November 2007, all the member states of the ASEAN signed a Charter based on a proposal by the ASEAN Eminent Persons Group, a track-two body: see Association of Southeast Asian Nations, The Asean Charter (Jakarta: ASEAN Secretariat, 2008) [ASEAN Charter]. The ASEAN Charter professes that one of the goals of ASEAN is to become a people-oriented community (art. 1(13)) and establishes the ASEAN Foundation so as to promote the people-to-people interaction (art. 15(1)), although it has no article that assigns a formal role in the decision-making process to the NGOs.

Membership in the Community is open to all "East Asian states" that accept all provisions of the Draft Charter without reservation: see Draft Charter, supra note 107, art. 39. Withdrawal from membership is recognized as a sovereign prerogative of each member state (art. 40).

Final Report of the East Asia Study Group (4 November 2002), online: ASEAN <http://www.aseansec. rg/viewpdf.asp?file=/pdf/easg.pdf $>$.

112 East Asian Vision Group, Towards an East Asian Community: Region of Peace, Prosperity and Progress (2001), online: Ministry of Foreign Affairs of Japan <http://www.mofa.go.jp/region/asiapaci/report2001.pdf>. Draft Charter, supra note 107, art. 2.

114 Ibid., art. 23. The East Asian Council shall consist not only of the heads of state or government of the member states, but also of the Secretary-General. The Draft Charter secures the intergovernmental character of the Council by denying voting rights to the Secretary-General. Regarding its composition, the East Asian Council follows a middle course between the ASEAN Charter and the Shanghai Cooperation Organization Charter, online: Eurasia Heritage Foundation <http://eurasianhome.org/ doc/shanghai_cooperation_organization_charter.doc $>$, both of which restrict the respective compositions of their highest decision-making bodies solely to the heads of state or government of the member states, and the Lisbon Treaty, supra note 79, art. 1(16), which designates the President of the European Commission as a full member of the European Council.

115 Draft Charter, supra note 107, art. 24. The Secretary-General or a representative designated by him or her is entitled to attend the meetings of the Council of Ministers without voting rights. The Chair of the Standing Committees, subsidiary bodies that may be set up by the Council of Ministers, will be a representative of the member state holding the presidency of the East Asian Council, whereas a chief officer of the Secretariat will assist as the deputy chair (art. 25(2)). 
institutions, whereas the East Asian Secretariat, ${ }^{116}$ the Eminent Persons Committee, ${ }^{117}$ and the National Parliamentarians Committee ${ }^{118}$ are non-governmental institutions whose members are independent of instructions from the governments of any member state. In addition to these institutions, a list of registered NGOs shall be set up to promote cooperation between the Community and its constituent civil societies. In principle, the East Asian Council will make decisions on the measures to be taken, based on the recommendations of the Council of Ministers. The Secretariat assists other institutions by communicating all the information and represents the interests of the Community in meetings. The Eminent Persons Committee and the National Parliamentarians Committee will discuss relevant matters and issue non-binding opinions to the two councils mentioned above upon requests by these councils or on their own initiative. The Secretariat will create a list of registered NGOs in accordance with regulations in order to establish a continuous and responsible relationship between the Community and NGOs that share its objectives. ${ }^{119}$ It will also be obligated to keep registered NGOs informed of the activities of the Community. ${ }^{120}$

Traditionally, the relations of the states in East Asia depended on the personal relationships between their political leaders. The Community is expected to construct lasting peace in the region based not only on friendship among political elites, but also on the solidarity of their respective peoples. In order to foster the peoples' awareness of and support for the activities of the Community, as well as constructing a bulwark against "cosmocracy," the Draft Charter establishes the Eminent Persons Committee, the National Parliamentarians Committee, and the list of registered NGOs. These institutions have unique particularities compared with other regional regimes. For example, the Draft Charter goes further than The

Ibid., art. 26.

Ibid., art. 27. A member of the Eminent Persons Committee shall be appointed by each member state from among persons who have held offices as the head of state or government, a cabinet minister, the president or speaker of the national parliament, or the chief justice or judge of the highest court of that member state. This is an arrangement that is thought of as especially suitable to East Asian societies where, traditionally, elders are highly respected and often play important roles as advisors or arbitrators. Ibid., art. 28. The National Parliamentarians Committee offers a meeting place of the peoples of the Community and a democratic channel for the peoples' voice. The regulation on the mode of appointment and the tenure of the members of the National Parliamentarians Committee is deferred to each national parliament. The Draft Charter provides no supervision by the Community over the appointment, respecting the political system of each member state, although several states in the Community now have a one-party regime or do not have an active parliament. Just like the Lisbon Treaty, supra note 79, art. 1(12), and the Protocol on the Role of National Parliaments in the European Union, 16 December 2004, [2004] O.J. C 310/204, art. 10, annexed to the Lisbon Treaty, each parliament is encouraged to make arrangements for co-operating with the Community, for example by establishing a committee in charge.

In East Asia, more and more NGOs play active roles in various fields, such as poverty reduction. In the Philippines, for example, some local governments have statutes allowing the allocation of some seats on the committees to representatives of NGOs.

Before the adoption of the ASEAN Charter, the Secretariat was "like a post office": see Rodolfo C. Severino, Southeast Asia in Search of an ASEAN Community: Insights from the Former ASEAN Secretary-General (Singapore: Institute of Southeast Asian Studies, 2006) at 20. In contrast, the Secretariat of the East Asian Community will have authority to attach its own opinion when it distributes documents to the Community institutions. The Secretariat will also assist the member states to translate those documents adopted under the Draft Charter into their respective official languages in order to maintain good relations with peoples of the countries: see Draft Charter, supra note 107, arts. 26(6), 45(5). 
ASEAN Charter, which provides no concrete institution through which the people can engage themselves in the activities of the community ${ }^{121}$ despite its glorious declaration that an aim of the Charter is to establish the "people-oriented ASEAN"122 and to make ASEAN "socially responsible." "123 On the other hand, the Draft Charter does not go so far as the EU, which declares its policy to make decisions from a standpoint "as close as possible to the citizen" and confers not only a consultative role but the power for law-making to the European Parliament. ${ }^{124}$ Different from pure cosmopolitan law-making in the EU, two consultative committees and the system for maintaining ties with NGOs by registration and communication offer alternative channels for peoples to have their voices heard in the intergovernmental discussions of the Community.

Particularly, the Draft Charter tries to create a system of hybrid law-making on specific issues related to designs for the future of a proposed East Asian Community. ${ }^{125}$ It is required for the East Asian Council or the Council of Ministers to consult with the National Parliamentarians Committee before making a decision concerning three issues: decisions responding to a serious and persistent breach of the fundamental principles of the Draft Charter that has consequently jeopardized the objectives of the Community, ${ }^{126}$ an application for admission, ${ }^{127}$ and the amendment of the Draft Charter. ${ }^{128}$ These issues are sufficiently important that democratic legitimacy should be secured. The opinions of two consultative bodies would strengthen both the political and moral dignity of the determinations of the Councils.

The institutions of the Community may invite registered NGOs to their meetings as observers without voting rights. ${ }^{129}$ The Community and the member states may also entrust appropriate tasks to registered NGOs. For example, the registered NGOs are expected to play an important role in the implementation of the common action for each policy area listed in Part Two of the Draft Charter. The Draft Charter proposes a "report and review" system consisting of three steps: adoption of a national action plan by each participant state, issuance of annual national reports on measures taken for the implementation of the national action plan, and review of the annual national reports by the Council of Ministers. The Council shall then issue appropriate recommendations and, in particular, publish the best practices of the

The Shanghai Cooperation Organisation Charter also has no provision on such institutions. ASEAN Charter, supra note 109, art. 1(13).

Ibid., Preamble.

Council of Europe, Committee of Ministers, Recommendation R(81)18 (1981).

For securing transparency and accountability of the Community, the Council of Economic and Financial Ministers, through the Board of Audit after it is established as the subsidiary body of the Council, shall inspect the draft report on the final account and the East Asian Council shall decide whether to approve it: see Draft Charter, supra note 107, art. 37(6).

Ibid., art. 36 (the Council of Ministers is called for consultation when it has included the reported situation on its agenda. "It shall report its determination to the East Asian Council and may recommend to the Member State in question appropriate measures to halt the breach" when the Council of Foreign Ministers determines that the member state in question has committed the accused acts or omission. The Council shall recommend such appropriate measures to the president of the East Asian Council as it deems necessary).

Ibid., art. 39.

Ibid., art. 41.

Ibid., art. 29. Every institution of the Community has authority to invite NGOs to their meetings as observers, either regularly or occasionally (art. 29(4)). 
national implementation measures. This system is further strengthened by the communications issued by the registered NGOs, describing the extent to which each common action plan has been implemented. These communications may be referred to in the review process. Although the Council of Ministers retains the freedom to refuse to recognize a complaint presented by registered NGOs, the Eminent Persons Committee and the National Parliamentarians Committee may initiate an inquiry based on the complaint and present an advisory opinion on it.

\section{CONCLUSION}

The emergence of de facto cosmopolitan law-making activities, as well as the institutionalization of cosmopolitan law-making, is gradually changing the transnational legal landscape. This article has pointed out that, in order for these innovative forms of lawmaking to be recognized as legitimate, NGOs should participate responsively as advisors or observers, putting their voices into the intergovernmental decision-making processes. ${ }^{130}$ It should also be noted that NGOs must make it clear that they are accountable to stakeholders around the world, disclosing information concerning their management and assessing each other's performance according to codes of conduct.

Following the legal experiment carried out by the European Union, which represents a purer version of cosmopolitan law-making, a number of proposals for institutionalizing cosmopolitan law-making activities have been made in various parts of the globe. Different regions may consider different types of cosmopolitan law-making appropriate, and as discussed above, the "Draft Charter of the East Asian Community" has decided to take a different approach from that of the EU, pointing the way toward another type of institutionalization: a hybrid of international and cosmopolitan law-making.

At present, more effort may still be needed to persuade nations in East Asia to adopt the Draft Charter and form a legal community. As one commentator puts it, "[w]hat [East] Asia needs is a leader to bring some version of the E[ast] A[sian] C[ommunity] to fruition." ${ }^{131} \mathrm{~A}$ strong political leadership is needed for realizing the proposed institutionalization to be sure, but ultimately the key to success is to ensure that the process adequately reflects the will of the stakeholders.

More and more cosmopolitan law is shaped each year through the activities of NGOs, international officials, and political leaders, who typically interact with each other across national boundaries. When making choices over diverse issues ranging from nuclear disarmament to regional integration, cosmopolitans and governmental representatives must

130 An empirical survey of the "influence" of NGOs on international negotiation has just started because there had been "a surprising lack of specification about what is meant by 'influence”": see Michele M. Betsill \& Elisabeth Corell, “Introduction to NGO Diplomacy” in Michele M. Betsill \& Elisabeth Corell, eds., NGODiplomacy: The Influence of Nongovernmental Organizations in International Environmental Negotiations (Cambridge: MIT Press, 2008) 1 at 7-8.

131 Juliana W. Chen, “Achieving Supreme Excellence: How China Is Using Agreements with ASEAN to Overcome Obstacles to Its Leadership in Asian Regional Economic Integration” (2007) 7 Chicago J. Int'l L. 655 at 656. There are skeptics who see the emerging regionalism in East Asia to be merely a defensive reaction towards U.S. policies regarding free trade agreements. Cf. Sungjoon Cho, “Defragmenting World Trade” (2006) 27 Nw. J. Int’l L. \& Bus. 39 at 56-57. 
be mindful that such a new form of law promotes the interests of the global community while conforming to the expectations of the relevant stakeholders. As an expression of the voices of the community, cosmopolitan law is expected to provide a better framework to serve the citizens of the world in this age of globalization. 